\title{
PENGARUH TERAPI REALITAS DENGAN MEDIA ZOOM MEETING UNTUK MENGURANGI KECEMASAN TERHADAP PEMBATASAN AKTIVITAS SOSIAL DI MASA PANDEMI COVID 19
}

\author{
Alfiatul Enia ${ }^{1}$, Issa Anisatul Azizah ${ }^{2}$, Nailil Hidayati Maulidika ${ }^{3}$, Nanik Siti Rohana ${ }^{4}$ \\ Program Studi Ilmu Keperawatan STIKES Cendekia Utama Kudus ${ }^{1-4}$ \\ Email: alfiatulenia@gmail.com
}

\begin{abstract}
ABSTRAK
Kecemasan merupakan sebuah bentuk ketidak beranian ditambah dengan kerisauan terhadap hal-hal yang tidak jelas. Kecemasan yang dialami oleh masyarakat ini menimbulkan dampak yaitu kurang tidur, kesulitan untuk berkonsentrasi, sering lupa dan sering marah. Saat ini masyrakat mengalami kecemasan Akibat pemberitaan covid 19 yang menjadikan pola pikir menjadi tidak fokus dan sulit untuk berkonsentrasi. Terapi realitas mempunyai tujuan untuk membantu individu menjadi rasional dan memiliki mental yang sangat kuat selain itu terapi realitas secara umum agar klien menemukan jalan yang lebih efektif untuk memenuhi kebutuhan-kebutuhannya. Tujuan dari penelitian ini digunakan untuk mengetahui pengaruh terapi realitas dengan media zoom meeting untuk mengurangi kecemasan terhadap pembatasan aktivitas sosial dimasa pandemi covid-19. Pada pengumpulan data peneliti menggunakan teknik total sampling dengan memberikan pretest-posttes melalui google form. Populasi dalam penelitian ini adalah remaja di desa Jetak sejumlah 98 orang kemudian metode sampelnya adalah menggunakan metode total sampling. Jenis pengumpulan data pada penelitian ini adalah non empirik tahapan persiapan ini menggunakan quasi experimental design Analisa data dalam penelitian ini dialakukan uji Paired T-Test dengan membandingkan pre test dan post test setelah tindakan Terapi Realitas dibeikan menggunakan aplikasi zoom meeting kepada klien. Hasil uji paired test menunjukkan bahwa nilai signifikansi sebesar 0.000 $<0.005$ menunjukkan adanya perbedaan yang signifikan antara pre test dan post test dapat dikatakan bahwa ada pengaruh pemberian terapi realitas menggunakan zoom meeting. Maka dapat disimpulkan bahwa signifikan yang artinya ada perbedaan setelah dilakukan treatment terapi realitas.
\end{abstract}

Kata Kunci: Kecemasan, Terapi Realitas, Pembatasan Aktivitas Sosial

\section{ABSTRACT}

Anxiety is a form of lack of courage coupled with worry about things that are not clear. Anxiety experienced by this community has an impact, namely lack of sleep, difficulty concentrating, often forgetting and often angry. Currently, people are experiencing anxiety due to the news of covid 19 which makes the mindset becomes unfocused and difficult to concentrate. Reality therapy has a goal to help individuals become rational and have a very strong mentality in addition to reality therapy in general so that clients find more effective ways to meet their needs. The purpose of this study was 
to determine the effect of reality therapy with zoom meeting media to reduce anxiety about social activity restrictions during the covid-19 pandemic. In collecting data, researchers used a total sampling technique by providing pretest-posttest via google form. The population in this study were teenagers in Jetak village with a total of 98 people, then the sample method was using the total sampling method. The type of data collection in this study is non-empirical. This preparation stage uses quasi-experimental design. Data analysis in this study was carried out by using a Paired T-Test by comparing pre-test and post-test after Reality Therapy was given using the zoom meeting application to the client. The results of the paired test show that a significance value of $0.000<0.005$ indicates a significant difference between the pre-test and post-test. It can be said that there is an effect of giving reality therapy using zoom meetings. So it can be concluded that it is significant, which means that there is a difference after the reality therapy treatment.

\section{Keywords: Anxiety, Reality Therapy, Social Activity Restriction}

\section{LATAR BELAKANG}

Kecemasan merupakan sebuah bentuk ketidak beranian ditambah dengan kerisauan terhadap hal-hal yang tidak jelas. Kecemasan yang dialami oleh masyarakat ini menimbulkan dampak yaitu kurang tidur, kesulitan untuk focus, sering lupa dan sering marah. Kecemasan dapat menyebabkan insomnia dan masalah tidur lainnya. Semakin sedikit waktu tidur maka semakin tingkat kecemasan akan semakin naik. Untuk mengatasi insomnia dapat melakukan caracara untuk meiningkatkan kualitas tidur, dengan meningkatatkan kulaitas tidur maka dapat mengurangi kecemasan. Kecemasan yang disebabkan oleh kesulitan untuk focus di masa pandemi covid-19 ini telah mengancam kesehatan fisik, psikis dan cara hidup sehati-hari. Secara tidak sengaja setiap hari masyarakat mendengar berita dan kemudian memikir cara-cara untuk melindungi diri dari paparan virus covid-19. Maslah yang timbul dalam masa pandemi ini selama di rumah juga harus tetap focus untuk belajar. Akibat pemberitaan covid 19 pola pikir menjadi tidak focus dan sulit untuk berkonsentrasi. Cara untuk meningkatakan fokus pada masa pandemi ini adalah dengan melakukan hal-hal yang diperlukan saja dan istirahat yang cukup untuk mengembalikan konsentrasi. Kecemasan juga bisa mempengaruhi daya ingat. Kecemasan juga dapat merubah emosi seseorang seperti mudah marah. Kecemasan yang dialami oleh berberapa masyarakat berbeda-beda, tentu saja hal ini berkontribusi terhadap kemarahan (Fitria dan Ifdil, 2020).

Pada masa pandemic ini banyak Negara yang terkena dampak virus covid19 termasuk Indonesia. Maka dari itu pemerintahan Indonesia mengambil kebijkan dengan menerapkan protocol kesehatan termasuk social distancing untuk mengurangi angka kejadian covid-19. Maka dari itu segala kegiatan di luar rumah pun di kurangi, pemerintah juga menganjurkan agar pembelajaran dilakukan dengan cara jarak jauh. Pembelajaran jarak jauh menggunakan platform aplikasi zoom meeting pun sering jadi pilihan karena aplikasi ini di nilai para mahasiswa bahawa lebih efisien dan praktis. Untuk itu dengan adanya aplikasi zoom meeting ini diharapakan dapat membantu dalam penyampaian terapi realitas berbasis online (Haqien dan Aqiilah, 2020).

Terapi realitas mempunyai tujuan untuk membantu individu menjadi rasional dan memiliki mental yang sangat kuat selain itu terapi realitas secara 
umum agar klien menemukan jalan yang lebih efektif untuk memenuhi kebutuhan-kebutuhannya. Terapis mempunyai tugas dasar yaitu dengan melibatkan klien dan kemudian membantu menghadapi kenyataan yang sedang dihadapi. Terapi bertugas sebagai pembimbing yang membantu klien agar bisa menilai tingkah lakunya sendiri secara realistis (Wulan, 2020).

Di Indonesia kasus covid-19 pertama kali terkonfirmasi pada tanggal 2 maret 2020 dengan angka yang masih rendah. Penambahan kasus terkonfirmasinya covid-19 pada bulan Mei berada pada angka 10.551 kasus dengan 800 orang meninggal di dunia, kemudian pada tanggal 16 juni 2020 kasus covid-19 naik dengan signifikan berjumlah 40.400 kasus dengan jumlah kematian sebanyak 2231. Pada update data terakhir (Satgas Covid-19) kaus positif terkonfirmasi covid-19 pada tanggal 1.3 maret 2021 yaitu 1.414 .741 orang, pasien yang sembuh dari covid ada 1.237.470 orang, sedangkan pasien yang meninggal karena covid-19 ada 38.329 orang. Pada tanggal 11 maret 2021 Jawa tengah berawa pada posisi ke 3 dengan jumlah kasus 160,063 orang. Sedangkan angka kejadian covid-19 di Kabupaten Kudus pada tanggal 13 maret 2021 berada pada angka 5.638 orang dengan kasus positf, pasien sembuh berjumlah 4.958 orang, 511 orang meninggal dunia (Pemkab Kudus, 2021).

Dengan adanya covid-19 ini menjadikan beberapa sektor dan beberapa bidang terkena dampak atas terjadinya pandemi saat ini sehingga terjadi pembatasan aktivitas social di berbagai wilayah di Indonesia khususnya pada kabupaten Kudus. pada data yang tertera di dinas kebupaten kudus menunjukan bahwa angka kecemasan tertinggi di Desa Jetak Kedungdowo Kaliwungu Kudus. Di satu sisi tuntutan untuk memulai kembali berbagai aktivitas social dan ekonomi semakin menguat ditandai dengan dilonggarkannya pembatasan social di beberapa daerah.

Beberapa penelitian mengatakan pembatasan aktivitas sosial dapat terjadinya kecemasan yang tinggi akan dialami oleh individu. Terapi realitas adalah teknik konseling yang bereorientasi pada tindakan membantu individu mengendalikan diri sendiri agar mampu menetapkan prioritas konseling terapi realitas individu dibantu untuk mengarahkan, melakukan monitoring dan melilai dirinaya sendiri serta dapat bertanggung jawab terhadap tujuan yang ingin dicapai. Pada penelitian ini, peneliti focus untuk mengatasi kecemasan pada saat pembatasan aktivitas sosial yang melibatkan aspek kognitif, aspek afektif dan aspek perilaku dengan tujuan untuk membantu individu menjadi rasional dan memeiliki mental yang kuat. Dengan menggunakan sistem WDEP (Wants, Direction, Evaluation, Planning) sebagai metode dalam membantu konselor dan lien membuat kemajuan dan penerapan teknik.

Berdasarkan studi pendahuluan yang dilkakukan oleh peneliti pada remaja MTs Nurul Huda didapatkan hasil wawancara kepada 10 siswa yang mengalami kecemasan terhadap pembatasan aktivitas sosial. Maka dari itu peneliti tertarik untuk malakukan penelitian terhadap remaja setempat tentang pengaruh terapi realitas dengan media zoom meeting untuk mengurangi kecemasan terhadap pembatasan aktivitas sosial di masa pandemi covid 19 (Solichah Novia, 2020)

\section{METODE}

Desain yang digunakan dalam penelitian ini menggunakan quasi experimental design pada tahapan persiapan penelitian ini menyiapkan identitas 
dan organisasi selain itu peneliti juga menyiapkan media zoom meeting, audio untuk menyampaikan terkait dengan terapi realitas untuk mengurangi kecemasan terhadap aktivitas social di masa pandemi.

Populasi dalam penelitian ini adalah remaja di Mts $\mathrm{Nu}$ Nurul Huda sejumlah 98 orang kemudian metode sampelnya adalah menggunakan metode total sampling. Pada penelitian ini alat ukur menggunakan kuisioner HARS (Hamilton Anxiety Rating Scale) adalah alat ukur kecemasan remaja yang didasarkan pada munculnya symptom pada individu yang mengalami kecemasan.

Penelitian mempersiapkan peralatan pelaksanaan terapi realitas yang diberikan menggunakan media zoom meeting dan peneliti menyebar kuesioner pre-test di grup whatssapp yang di isi melalui google form setelah itu peneliti melakukan pemeriksaan kelengkapan kuesioner. Kemudian peneliti melakukan treatment dengan menggunakan sistem WDEP (Wants, Direction, Evaluation, Planning) sebagai metode dalam membantu konselor dan lien membuat kemajuan dan penerapan teknik. Setelah itu peneliti melakukan terminasi terapi dan meminta responden untuk mengisi kuisioner melalui google form tentang respon kecemasan setelah dilakukan treatment terapi realitas untuk post test.

Jenis pengumpulan data pada penelitian ini adalah non empirik tahapan persiapan ini menggunakan quasi experimental design Analisa data dalam penelitian ini dialakukan uji Paired T-Test dengan membandingkan pre test dan post test setelah melakukan treatment Terapi Realitas dibeikan menggunakan aplikasi zoom meeting kepada klien.

Karakteristik Responden

Table 1

Distribusi Fekuensi Kasus Berdasarkan Umur Pengurus Osis di Mts Nu Nurul Huda

\begin{tabular}{ccc}
\hline Umur & F & $\%$ \\
\hline 13 & 82 & 83.7 \\
14 & 15 & 15.3 \\
15 & 1 & 1.0 \\
\hline Total & 98 & 100
\end{tabular}

Berdasarkan table 1 menunjukkan bahwa mayoritas umur responden adalah 13 tahun sebanyak $82(83 \%)$ siswa maupun siswi.

Table 2

Distribusi Fekuensi Kasus Berdasarkan Jenis Kelamin Pengurus Osis di Mts Nu Nurul Huda

\begin{tabular}{ccc}
\hline Jenis Kelamin & Frekuensi & Persen \\
\hline Laki Laki & 37 & 37.8 \\
Perempuan & 61 & 62.2 \\
\hline Total & 98 & 100 \\
\hline
\end{tabular}

Berdasarkan table 2 menunjukkan bahwa mayoritas jenis kelamin responden adalah Perempuan 61 (62.2\%) responden. 


\section{HASIL DAN PEMBAHASAN}

\section{Kecemasan}

Kecemasan atau Anxiety yang dialami remaja ini akan bisa terjadi insomnia dan masalah tidur lainnya. Semakin sedikit waktu tidur maka semakin meningkat akan terjadi peningkatan kecemasan (Fitria Linda, Ifdil Ifdil 2020).

Berdasarkan table 3 diketahui bahwa rata-rata hasil kuesioner pre-test dari tingkat kecemasan pada terhadap pembatasan aktivitas sosial di masa pandemic covid-19 adalah sebagai berikut:

Tabel 3 Distribusi Frekuensi hasil penilaian Pre-Test pada responden

\begin{tabular}{llll}
\hline No & Tingkat Kecemasan & Frekuensi & Presentase \\
\hline $\mathbf{1}$ & Sedang & 8 & 8.2 \\
$\mathbf{2}$ & Tinggi & 90 & 91.8 \\
\hline Total & & $\mathbf{9 8}$ & $\mathbf{1 0 0}$
\end{tabular}

Hasil penelitian dari pre-test menyatakan bahwa yang mengalami tingkat kecemasannya tinggi pada siswa siswi remaja di MTs Nu Nurus Huda sebanyak $90(91.8 \%)$ sedangkan $8(8.2 \%)$ responden mengalami tingkat kecemasan kategori sedang.

Table 4 Distribusi Frekuensi hasil Post Test berdasarkan Tingkat Kecemasan Responden

\begin{tabular}{llll}
\hline NO & TINGKAT & FREKUENSI & PRESENTASE \\
& KECEMASAN & & \\
\hline $\mathbf{1}$ & Rendah & 19 & 19.4 \\
$\mathbf{2}$ & Sedang & 2 & 2.0 \\
$\mathbf{3}$ & Tidak Cemas & 77 & 78.6 \\
\hline TOTAL & & $\mathbf{9 8}$ & $\mathbf{1 0 0 . 0}$ \\
\hline
\end{tabular}

Hasil penelitian dari prot-test menyatakan bahwa yang mengalami tingkat kecemasannya rendah pada siswa siswi remaja di MTs Nu Nurus Huda sebanyak $19(1948 \%)$ sedangkan $2(2.0 \%)$ responden mengalami tingkat kecemasan kategori sedang dan responden yang tidak cemas adalah 77 (78.6\%).

Table 5 rekapitulais penilaian Pre-test dan Post-test

\begin{tabular}{cccc}
\hline No & Data & Pre Test & Post Test \\
\hline $\mathbf{1}$ & Skor Tertinggi & 10 & 4 \\
$\mathbf{2}$ & Skor Terendah & 4 & 0 \\
$\mathbf{3}$ & Mean & 9.36 & 1.35 \\
$\mathbf{4}$ & Median & 10.00 & 1.00 \\
\hline $\mathbf{5}$ & Standar Deviasi & $\mathbf{1 . 1 2 4}$ & $\mathbf{0 . 8 1 4}$ \\
\hline
\end{tabular}

Pada table 4.5 diatas dapat diartikan kesimpulannya adalah bahwa rata rata dari pengisian kuesioner pre-test dan post-test mengalami penurunan pada angka kecemasan. Hasil dari pre-test terdapat rata-rata 9.36 sedangkan post-test 1.35.

Table 6 Hasil uji paired sampel test

\begin{tabular}{lllllll}
\hline & N & Mean & $\begin{array}{l}\text { Std. } \\
\text { Error } \\
\text { Mean }\end{array}$ & Df & t & $\begin{array}{l}\text { Sig. (2- } \\
\text { teiled) }\end{array}$ \\
\hline Klompok & 98 & 7.92857 & $\mathbf{0 . 1 5 9 0 6}$ & 97 & 49.847 & $\mathbf{0 . 0 0 0}$ \\
\hline
\end{tabular}




\section{Intervensi}

Analisis paired sampel test digunakan untuk menguji hipotesis apakah terdapat perbedaan tingkat kecemasan antara sebelum dan sesudah diberikan terapi realitas

Berdasarkan table 4.6 bahwa uji paired test nilai signifikansi sebesar 0.000 $<0.005$ menunjukkan adanya perbedaan yang signifikan antara pre test dan post test dapat dikatakan bahwa ada pengaruh pemberian terapi realitas menggunakan zoom meeting.

\section{KESIMPULAN}

Dari hasil treatment terapi realitas menggunakan media zoom meeting yang telah dilaksanakan oleh peneliti pada tahap evaluasi berdasarkan dari hasil kuesioner pre-test dan post-test. Terjadinya perubahan tingkat kecemasan pada responden bahwa pemeberian terapi realitas menggunakan media zoom meeting mampu menurunkan angka kecemasan.

\section{UCAPAN TERIMAKASIH}

Penelitian ini dapat dilaksanakan dengan baik berkat bantuan dari berbagai pihak, untuk itu peneliti mengucapkan terimakasih kepada Anita Dyah Listyarini Ns. Anita Dyah Listyarini,M.Kep,Sp.Kep.Kom. Sebagai pembimbing, Evi Noor Hidayah S.Pd sebagai Pembina osis, pengurus osis Mts Nu Nurul Huda sebagai responden yang telah bersedia meluangkan waktunya untuk mengikuti penelitian ini.

\section{DAFTAR PUSTAKA}

Dharma, K.K (2011) Metodelogi Penelitian Keperawatan: Panduan Melaksanakan dan Menerapkan Hasil Penelitian. Jakarta: Trans Info Medika

Fadil, dkk. 2020. Faktor yang Mempengaruhi Kecemasan pada tenaga Kesehatan dalam Upaya Pencegahan Covid-19. Jurnal pendidikan Keperawatan Indonesia. $6(1): 57-65$

Fitria Linda, Ifdil. 2020. Kecemasan Remaja pada Masa Pandemi Covid-19. Jurnal Education (Jurnal Pendidikan Indonesia). 6 (1) : 1-4

Haqien Danin, Aqiilah. 2020. Pemanfaatan Zoom Meeting untuk Proses Pembelajaran Pada Masa Pandemi Covid-19. 5 (1) : 51-56

Muhyiddin dan Hanan. 2020. Catatan Editorial Edisi Khusus Tentang Covid-19 new Normal dan Perencanaan Pembangunan. Jurnal of Development Planning. 4 (2) : 4-7

Nurhayati dan Navianti. 2020. Pengaruh SPSS Terhadap Hasil Belajar pada Materi Statistika Deskriptif. Jurnal Program Studi Pendidikan Matematika. 9 (1): 101-107

Solichah Novia. 2020. Konseling Pendekatan Terapi Realitas untuk Mengatasi Prokrastinasi Akademik. Jurnal Penelitian Psikologi. 11 (1) : 9-15

Wulan Ratna. 2020. Terapi Realitas dan Konsep Sabar dalam Physical Distancing Mahasiswi di Asrama Astri Aulia. Jurnal of Guidance and counseling. 4 (2) : 259-289 